\title{
The Feasibility of Information Technology Infrastructure according to the Regulation of the Minister of National Education No.40 of 2008: A Case Study at SMK Palembang City
}

\author{
Supriyati, Darius Antoni \& Muhamad Akbar \\ Universitas Bina Darma \\ Email: supriyati0914@yahoo.com
}

\begin{abstract}
The feasibility of infrastructure to determine the level and feasibility of Information Technology Vocational Schools in Palembang City. Based on research according to Permendiknas No. 40 of 2008 contains computer laboratory furniture, including: the ratio of the number of student chairs and desks, the ratio of the number of teacher chairs, computer equipment, and educational media. This research methodology uses quantitative methods, where the data collection method is obtained from a questionnaire of information users as respondents. Data analysis used SPSS version 20 for data processing. The analysis results obtained according to Permendiknas No. 40 of 2008 and referring to O'Brien's theory, namely as follows: SMK Negeri 1, SMK Negeri 2, SMK Negeri 3, SMK Negeri 4, and SMK Negeri 5 Palembang, the achievement in the category is less feasible, namely with an average percentage of $5.6 \%$, while $27.77 \%$ with a decent category achievement and 66.7 with very decent category.
\end{abstract}

Keywords: feasibility, information technology infrastructure, vocational high school (SMK)

\section{Introduction}

Through this transformation process, the government can optimize the use of advances in information technology to simultaneously serve the community in the field of transformation of the education system. Thus all educational institutions can be organized by the National Education Standards Agency (BSNP) and the Education Assessment Center (Puspendik). Information technology facilities and infrastructure in the implementation of the education system for Vocational High Schools include: implementation of Online Computer-Based National Examinations, Computer-Based National Examination Trayout, Online New Student Registration (PPBD), Teacher Competency Examination, and Computer Technology Learning Process. All implementation processes are carried out in a computer laboratory. In general, the learning process in Vocational High Schools is 30\% theory and $70 \%$ practice, based on these circumstances, the need for information technology infrastructure facilities for practice and other activities is very high. State Vocational High Schools in Palembang City, there are 8 Vocational High Schools SMKN 1 Palembang, SMKN 2, SMKN 3, SMKN 4, SMKN 5, SMKN 6, SMKN 7, and SMKN 8, and there are 3 types of vocational fields, including: Engineering, Business Management, as well as Crafts and Fine Arts. Each school has information technology infrastructure and the use of different technology according to the field of majors that each school has, but in general all schools have utilized adequate information technology infrastructure especially in implementing the implementation of the Online Computer-Based National Examination, Computer-Based National Examination Trayout, Online New Student 
Registration (PPBD), Teacher Competency Exam. All learning processes are carried out in a computer laboratory. Furthermore, according to the Decree of the Minister of National Education of the Republic of Indonesia Number 129a / u / 2004 concerning Minimum Service Standards in the Education Sector (SPM) for SMK article 3 paragraph 2, one of which explains that $90 \%$ of schools must have facilities and infrastructure at least according to the technical standards set nationally. The standard of computer laboratory facilities and infrastructure is also stipulated in the Regulation of the Minister of Education of the Republic of Indonesia No. 40 of 2008 .

The procurement of practical facilities, especially computer equipment that meets the criteria for use, is indeed a big problem in the procurement of these practical facilities, because to meet the requirements above, a large amount of money is required. The obstacles faced by schools regarding computer laboratory facilities include: Hardware components, Software Components, Human Resources Components (Brainware), Computer Network Components (Netware), Data Resource Components (Dataware). In general, the problems faced are the number of computer facilities that are ready to use so that they are in accordance with the number of existing users and also the network systems that are connected to each user, most of these facilities are not in accordance with Permendiknas No. 40 of 2008, which includes eligibility:
a. Laboratory Furniture
b. Educational Equipment
c. Educational Media
d. Other Equipment.

Facilities and infrastructure for technological information infrastructure in computer laboratories are vital needs that must be met by every school institution, especially the Technical Vocational High School for Engineering and Business Management in Palembang City. This situation needs to be conducted research that will provide direction on the feasibility of information technology infrastructure in Vocational High Schools, where this research includes: Introduction, literature review, research methodology, conclusions and suggestions.

\section{Literature Review}

A feasibility study is a study that will be used to determine whether the system project development is feasible to continue or stop. The feasibility study is also called a high point review (Jogiyanto, 2008). Meanwhile, according to Kasmir and Jakfar (2003), it is an activity that studies in-depth means of an activity or business to be carried out, to determine whether a business is feasible or not. A feasibility study is a study of whether or not an investment project can be implemented successfully (Suad Husnan, 2002)

Information technology infrastructure consists of a set of software tools and applications needed to run a large company as a whole. According to Agil (2015) IT infrastructure is defined as shared technology resources that provide a platform for detailed enterprise information system applications. 
According to the regulation of the Minister of National Education No. 40 of 2008 for vocational high schools and vocational madrasah aliyah (SMK / MAK) assessment / consideration in the feasibility study of information technology infrastructure: Laboratory Furniture, Educational Equipment, Educational Media and Other Equipment. Meanwhile, according to James O'Brien (2010) Information Technology Facilities Standards which show the basic conceptual framework for various components and activities of information systems. Information systems depend on human resources (end users and information systems experts), hardware (machines and media), software (programs and procedures), data (data and knowledge bases), and networks (communication media and network support) to perform input. The processing, output, storage, and control activities that transform data resources into information products.

\section{Research Method}

By using the evaluative case study method. The type of data used is in quantitative form which is directly related to the numbers or statistical analysis of the feasibility analysis of information technology infrastructure in SMK Palembang City. (Ine I. Amirman and Arifin Zainal, 1993)

This research took place at the Vocational High School in Palembang City, with the research design, as follows:

Identify the background of the problem, identify the research problem. Implementation at this stage the researcher acts as a research implementer as well as a human instrument looking for data information, namely documentation, observation and documentation. Data analysis is carried out after the researcher has collected data, data analysis is carried out by giving a score of each -Each instrument and see the percentage of each total instrument or variable. Recommendation of analysis results is to provide recommendations from the results of the analysis shown from each instrument score.

The data collection methods used in this study are:

1. Primary data is obtained through:

a. Questionnaire: conducted by providing a written list of questions used to investigate the feasibility of information technology infrastructure at SMK Negeri Palembang City.

b. Observation: Data collection was carried out by direct observation of the research object, namely all SMK Negeri Engineering and business management related to the investigation of the feasibility of information technology infrastructure at SMK Negeri Palembang City.

According to Sugiyono (2013), population is a generalization area consisting of objects or subjects that have certain quantities and characteristics that are determined by researchers to be studied and then conclusions are drawn. The following is the population of vocational high schools in Palembang for engineering and business management majors. In this study the researchers took 6 Vocational High Schools in Palembang City because based on direct observations or observations made by researchers, these schools in general are referred to as reference schools and accredited A must also have a computer laboratory. because the compulsory skills of priority include computer network engineering, robotics, animation for 
management business schools, including computerized accounting and administrative computerization as the main subject or. Therefore, the researcher is interested in taking the middle level technical and business management vocational school in Palembang City as the research object.

Table 3.1. Research Population

\begin{tabular}{llll}
\hline No & Nama Sekolah & Jabatan & Responden \\
\hline 1 & SMK Negeri 2 Palembang & Wakasarpras, Teknisi dan Guru & 3 \\
\hline 2 & SMK Negeri 1 Palembang & Wakasarpras, Teknisi dan Guru & 3 \\
\hline 3 & SMK Negeri 3 Palembang & Wakasarpras, Teknisi dan Guru & 3 \\
\hline 4 & SMK Negeri 4 Palembang & Wakasarpras, Teknisi dan Guru & 3 \\
\hline 5 & SMK Negeri 5 Palembang & Wakasarpras, Teknisi dan Guru & 3 \\
\hline 6 & SMK Negeri 8 Palembang & Wakasarpras, Teknisi dan Guru & 3 \\
\hline \multicolumn{5}{c}{ Jumlah } & $\mathbf{1 8}$ \\
\hline
\end{tabular}

Source: Data for SMK in Palembang City 2017

The sample is a part or representative of the population under study. To determine the size of the sample if the subject is less than 100, it is better to take all of them so that the research is a population study. If the subject is larger, it can be taken between 20-25\% (Arikunto, 2010). So the number of samples is as many as 18 respondents from the Vocational School of Engineering and Business Management Department. The percentage or score from the range used is in the questionnaire or questionnaire, as for the terms of the score from the value range and score category, namely Score 5 Very Eligible, Score 4 Eligible, Score 3 Enough Score of 2 Unworthy and Score of 1 Very Inadequate. To find out the total score to assess to be the percent with the highest character, namely $100 \%$ of each variable. A feasibility study is also called a high point review (Jogiyanto, 2008). Meanwhile, according to Kasmir and Jakfar (2003) a feasibility study is a study of whether or not an investment project can be implemented successfully (Suad Husnan, 2002). According to Safyan, (2004) the two criteria for assessing feasibility are the cost required and the value to be achieved and the Business Management.

To analyze the effect of the variables under study. The analysis conducted in this study is using inference statistics. namely through Pearson's analysis which is a statistical test for interval-scale variables where alternative answers to the questionnaire filled out by respondents will be given a Likert scale, namely 5, 4, 3, 2, 1 for each question that has a range of values as follows:

Table 3.2. Character Score

Character Score

Very feasible 5 


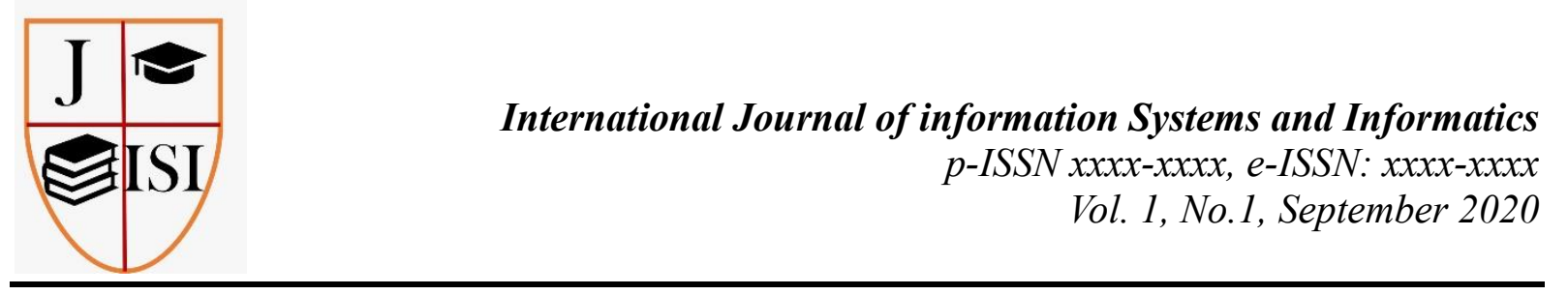

\begin{tabular}{llc}
\cline { 2 - 2 } Feasible & 4 \\
\cline { 2 - 2 } Moderate & 3 \\
\cline { 2 - 2 } Not feasible & 2 \\
Very not feasible & 1
\end{tabular}

To find out the total score to assess the percent with the highest character, namely $100 \%$ of each variable with the formula:

$$
\text { Total score }=\frac{\text { Actual Score }}{\text { Ideal Score }} \times 100 \%
$$

Actual score $=$ Answers of all respondents

Ideal score $=$ score $/$ highest value $/$ all respondents are assumed to choose the highest answer.

The actual score is the answer of all respondents to the questionnaire that has been submitted. The ideal score is the highest score or weight or all respondents are assumed to choose the answer with the highest score. An explanation of the weight of the actual score can be seen in the following table:

Table 3. Criteria for Percentage of Respondents' Responses

\begin{tabular}{cll}
\hline No. & \% Total Score & Criteria \\
\hline 1. & $20.00 \%-36.00 \%$ & Very not agree \\
\hline 2. & $36.01 \%-52.00 \%$ & Not agree \\
\hline 3. & $52.01 \%-68.00 \%$ & Moderate \\
\hline 4. & $68.01 \%-84.00 \%$ & Agree \\
\hline 5. & $84.01 \%-100 \%$ & Very agree \\
\hline
\end{tabular}

Source: Umi Narimawati (2007)

Based on the results of preliminary observations, theoretical studies and journals from previous research, the authors build a framework of thinking about the feasibility of technology information infrastructure in Vocational High Schools in Palembang City. This study aims to determine the feasibility analysis of information technology infrastructure for SMK in Palembang City. The first thing to do is look for problems in research on information technology infrastructure. The lack of optimal IT infrastructure at State Vocational High Schools in Palembang regarding computer laboratory facilities. In this study the researchers used 2 theories in discussing the feasibility of Information Technology infrastructure, namely Regulation of the Minister of National Education No. 40, 2008 and O'brien's theory. In accordance with Permendiknas No. 40 of 2008 Eligibility IT infrastructure facilities and infrastructure at Palembang City State Vocational High Schools include: Feasibility of 


\section{International Journal of information Systems and Informatics}

p-ISSN $x x x x x-x x x x$, e-ISSN: $x x x x-x x x x$

Vol. 1, No.1, September 2020

Laboratory Furniture, Feasibility of Educational Equipment, feasibility of educational media, feasibility of other equipment. Meanwhile, according to the theory of IT feasibility standards include the feasibility of hardware components (hardware), software components (software), human resource components (brainware), computer network components (netware), data resource components (dataware).

\section{Finding and Discussion}

\subsection{Assessment of IT Infrastructure Feasibility According to Permendiknas No. 40 of 2008 and O'Brien's theory}

The sample in this study is the manager and person in charge of the computer lab room and facilities, the manager of the computer lab space and facilities, on average each school is directly involved in the responsibility for all facilities and activities in the lab room and is given a mandate or direct assignment by the principal consisting of of 3 people, among others: 1 Waka Sarpras, 1 Technician / Teacher and Technician, and 1 Computer Teacher. The study involved all vocational high schools in the city of Palembang which were considered to have more computer use intensity because they had computer subjects, both general and productive subjects, specifically expertise, namely technical vocational and business management which consisted of 6 schools, including: SMK Negeri 1 Palembang, SMK Negeri 2 Palembang, SMK Negeri 3 Palembang, SMK Negeri 4 Palembang, SMK Negeri 5 Palembang, SMK Negeri 6 Palembang, SMK Negeri 8 Palembang. In assessing the feasibility of computer laboratory information technology infrastructure at Vocational High Schools (SMK) in Palembang, researchers assessed the feasibility according to Permediknas No. 40 of 2008 which consists of: laboratory furniture, educational equipment, educational media, other equipment, as well as assessment of the feasibility of IT infrastructure based on O'brien's theory according to Turban, Rainer and Potter. (2003: 11) consisting of human resources (end users and information system experts), hardware (machines and media), software (programs and procedures), data (data and knowledge bases), and networks (communication media and network support ) to perform input, processing, output, storage, and control activities that convert data resources into information products.

\section{Variable Description General Provisions}

From the results of the information dissemination of observational data in the Vocational High School of Engineering and Business Management in Palembang City, namely the completeness of the size ratio deficiency must be fulfilled by adding space either by borrowing space for the conversion of the theory room function into a computer practice room such as during the UNCBT implementation process or activities. lessons that require adequate space size ratios such as the implementation of the UKG (Teacher Competency Test) for SMK in Palembang City.

Variable Description of Computer Laboratory Furniture

From the results of the information dissemination of observational data in the Vocational High School of Engineering and Business Management in Palembang City, namely the completeness of the lack of the ratio of the number of computer laboratory furniture must be fulfilled by 


\section{International Journal of information Systems and Informatics}

p-ISSN $x x x x x-x x x x$, e-ISSN: $x x x x-x x x x$

Vol. 1, No.1, September 2020

adding by borrowing theoretical chairs and tables for the purposes of computer laboratory practice, but this is only done during activities compulsory such as the implementation of UNCBT, implementation of UKG and implementation of the Final Competency Examination.

Variable Description of Educational Equipment

From the results of the information dissemination of observational data in the Vocational High School for Engineering and Business Management in Palembang City, it is indeed a big problem and the problem of educational equipment is that on average most schools still do not match the minimum ratio of existing computer equipment to what is needed. However, every SMK in Palembang City, especially Engineering and Business Management, takes a policy to overcome these problems by collaborating with SMKs or the business world that provides computer or educational equipment rental to meet the ratio of educational equipment, this is often done during the implementation of UNCBT, UKG, or Competency Examination whose activities have been determined in accordance with government programs and are sustainable in nature.

Description of Other Equipment Variables

From the results of the information dissemination of observation data at the Vocational High School of Engineering and Business Management in Palembang City, that as a whole there is maybe only a few computer laboratory rooms that are not yet effective, such as examples of wall clocks that are not alive because of running out of batteries, trash bins that are sometimes borrowed for local theory.

Description of Human Resources Variables

From the results of the information dissemination of observation data in Vocational High Schools

Engineering and Business Management in Palembang City, namely Human Resources are categorized as feasible and even very feasible to show that technical personnel are competent, indeed sometimes there is a lack of competent human resources that still occurs in several vocational schools in Palembang, the principal is as a policy maker, namely by borrowing or renting external technical personnel such as from Multikom, MDP or other computer repair and repair service companies.

Description of Hardware Resource Variables

From the results of the information dissemination of observation data at the Vocational High School for Engineering and Business Management in Palembang City, only 1 observer stated that it was not feasible and the rest said it was feasible and very feasible, this is because the school issued a policy to complete the minimum ratio of computer laboratory hardware facilities by borrowing in the laboratory other schools or rent from other computer sales and rental business entities.

\section{Description of Software Resource Variables}

From the results of the information on the distribution of observation data at the Vocational High School for Engineering and Business Management in Palembang City, there were several schools that stated that it was not feasible, because from some computers that were borrowed

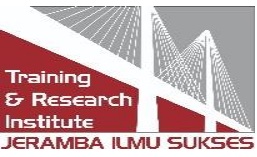




\section{International Journal of information Systems and Informatics}

p-ISSN $x x x x x-x x x x$, e-ISSN: $x x x x-x x x x$

Vol. 1, No.1, September 2020

or rented, sometimes the existing software was not in accordance with the needs and there were even some computer facilities whose hardware drivers were not exist or not installed.

\section{Description of Data Resource Variables}

From the results of the information on the distribution of observation data at the Vocational High School for Engineering and Business Management in Palembang City, there were several schools that stated that it was not feasible, because from some computers that were borrowed or rented, sometimes the existing software was not in accordance with the needs and there were even some computer facilities whose hardware drivers were not complete installed.

\section{Description of Network Resource Variables}

From the results of the information dissemination of observation data at the Vocational High School for Engineering and Business Management in Palembang City, there are several networks that have not been running at the time of the implementation of the UNCBT, UKG or Competency Examinations that have been implemented, this is because the local network has not been fully installed, and also server support capacity is still not sufficient, and there are also some problems in the server that sometimes technical personnel cannot handle it properly.

The analysis results obtained according to Permendiknas No. 40 of 2008 and referring to O'Brien's theory, namely as follows: SMK Negeri 1, SMK Negeri 2, SMK Negeri 3, SMK Negeri 4, and SMK Negeri 5 Palembang, the achievement in the category is less feasible, namely with an average percentage of $5-22 \%$, while $23-100 \%$ achieved a decent and very decent category. The results of the feasibility analysis of information technology infrastructure in computer laboratories at technical and business management vocational high schools in the city of Palembang according to Permendiknas No. 40 of 2008. For indicators of general provisions with a percentage result of $51.1 \%$ of respondents feel very worthy, $33.3 \%$ feel worthy, $5.6 \%$ who answer are not appropriate, indicators of computer laboratory furniture with a percentage result of $66.7 \%$ of respondents feel very worthy , $27.8 \%$ felt feasible, and $5.6 \%$ answered that it was not feasible, the indicator of educational equipment was $66.7 \%$ of respondents felt very worthy, $27.8 \%$ felt it was feasible, and $5.6 \%$ answered that it was not feasible, for equipment indicators others with a percentage of $66.7 \%$ of respondents felt very worthy, $27.8 \%$ felt worthy, and $5.6 \%$ who answered less worthy. And the results of the analysis according to O'Brien's theory are the analysis of the feasibility of information technology infrastructure in computer laboratories at technical high schools and business management in Palembang according to O'Brien's theory. For the human resource indicator with the percentage of $55.6 \%$ of respondents felt very worthy, $44.4 \%$ felt worthy, for the hardware resource indicator with the percentage results of $66.7 \%$ of respondents felt very worthy, $27.8 \%$ felt worthy, and $5,6 \%$ who answered inadequate, for the indicator of software resources with a percentage of $72.2 \%$ of respondents felt very worthy, $11.1 \%$ felt worthy, and $16.7 \%$ who answered less feasible, for indicators of data resources obtained results with the percentage of $61.1 \%$ of respondents felt very worthy, $22.2 \%$ felt that they were worthy, and $16.7 \%$ who answered that they were not.

Analisis Ketersediaan Sarana dan Perasarana Informasi Manajemen Menurut Teori James O'Brien (2010,p32) Hasil analisis jawaban responden dari data angket yang telah di dibagikan mengenai pemenuhan kelayakan sarana dan prasaranan laboratorium komputer menurut teori

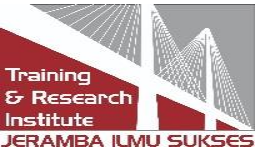




\section{International Journal of information Systems and Informatics}

p-ISSN $x x x x x-x x x x$, e-ISSN: $x x x x-x x x x$

Vol. 1, No.1, September 2020

O'Brien mengenai sarana infrastruktur teknologi informasi, dan diperoleh jawaban dari ratarata terbanyak atau tertinggi yaitu sebagai berikut : 


\subsection{Program and Follow Up}

In this research concluded that according to the provisions of Permendiknas No. 40 of 2008, there are several schools that have not been categorized as feasible for implementation in Palembang City Vocational High School. The causes of this include: minimal infrastructure procurement costs and the school's policy to complete laboratory facilities by collaborating with computer services such as MDP, Multikom in terms of compliance with computer equipment and software and network resources. From the results of the follow-up carried out by the school, the researchers advised school leaders and facility staff to pay more attention to the feasibility of computer laboratories by issuing policies regarding appropriate computer laboratory facilities and infrastructure.

\section{Conclusion}

Based on the results of the discussion regarding the feasibility analysis of information technology infrastructure in computer laboratories at technical and business management vocational high schools in Palembang, the following conclusions are obtained:

a. The analysis results obtained according to Permendiknas No. 40 of 2008 and referring to O'Brien's theory, namely as follows: SMK Negeri 1, SMK Negeri 2, SMK Negeri 3, SMK Negeri 4, and SMK Negeri 5 Palembang, the achievement in the category is less feasible, namely with an average percentage of $5-22 \%$, while $23-100 \%$ achieved a decent and very decent category. The results of the feasibility analysis of information technology infrastructure in computer laboratories at technical and business management vocational high schools in the city of Palembang according to Permendiknas No. 40 of 2008. For indicators of general provisions with a percentage result of $51.1 \%$ of respondents feel very worthy, $33.3 \%$ feel worthy, 5.6\% who answer are not feasible, indicators of computer laboratory furniture with a percentage result of $66.7 \%$ of respondents feel very worthy , $27.8 \%$ felt feasible, and $5.6 \%$ answered that it was not feasible, the indicator of educational equipment was $66.7 \%$ of respondents felt very worthy, $27.8 \%$ felt it was feasible, and $5.6 \%$ answered that it was not appropriate, for equipment others with a percentage of $66.7 \%$ of respondents felt very worthy, $27.8 \%$ felt worthy, and $5.6 \%$ who answered less worthy ..

b. Based on the research objectives to determine the level of availability of management information facilities and infrastructure according to Permendiknas No. 40 of 2008 and O'Brien's theory, it is concluded from the results of the discussion that on average the availability of facilities and infrastructure is sufficient based on: general provisions, laboratory furniture, educational equipment, other equipment., human resources, hardware resources, software resources, data resources and network resources.

\section{References}

Agil. (2015). Pengertian Infrastruktur Teknologi Informasi. diakses tanggal 06/11/2016, 15:59. https://agilbox.wordpress.com/2015/01/21/pengertian- infrastruktur-teknologiinformasi/

Arikunto, S. (2010). Prosedur penelitian: Suatu Pendekatan Praktik. (EdisiRevisi). Rineka Cipta. Jakarta.

Amirman, I.I., \& Arifin, Z. (1993). Penelitian Dan Statistik Pendidikan. Bumi Aksara. Jakarta. Kasmir \& Jakfar. (2003). Studi Kelayakan Bisnis. Kencana Prenada Media Group. Jakarta 
Keputusan Menteri Pendidikan Nasional Republik Indonesia Nomor 129a/u/2004 tentang

Standar Pelayanan Minimal Bidang Pendidikan (SPM) untuk SMK

O’Brien, J. A. diterjemahkan oleh Dewi Fitriasari dan Deny Amos Kwary. (2005). Pengantar Sistem Informasi. Jakarta. Salemba Empat

Peraturan Menteri Pendidikan Republik Indonesia No. 40 Tahun 2008 tentang Standar Sarana Dan Prasarana Sekolah Menengah Kejuruan/Madrasah Aliyah Kejuruan (SMK/MAK) beserta lampirannya.

Safyan, I. (2004). Studi Kelayakan Bisnis, EdisiPertama, Penerbit Graha Ilmu, Yogyakarta.

Sugiyono. (2013). Statistika Untuk Penelitian. CV. Alfabeta. Bandung.

Husnan, S. (2008). Manajemen Keuangan: Teori dan Penerapan Buku 1. Edisi 4. BPFE. Yogyakarta.

Turban, Rainer, \& Potter. (2003). Information Technology. Wiley, USA.

\section{Copyrights}

Copyright for this article is retained by the author(s), with first publication rights granted to the journal.

This is an open-access article distributed under the terms and conditions of the Creative Commons Attribution license (http://creativecommons.org/licenses/by/4.0/) 